\title{
"I AM AN INTELLECTUAL". WAR, YOUTH AND Higher EduCATION IN GOMA (EASTERn CONGO)
}

\author{
Silke OLDENBURG*
}

\begin{abstract}
The purpose of this paper is to explore, at an empirical level and with a processual view, the relationship between higher education, war, and youths' aspirations in Eastern Congo. Students are a relevant social group and an adequate ethnographic lens to describe moments and processes of self-staging, identity formation and social positionality. Therefore, this article explores how students imagine their life chances and how they aspire to accomplish their yearnings in the future. I argue that university is a contested space that mirrors society. Thus, students' experiences and social practices in relation to the educational realm offer important insights into the complex nature of patrimonial politics, shifting power balances, social belonging and intimacy, which are, as I argue, at the heart of the youthful imagination of a better future.
\end{abstract}

Keywords - Higher education; youth; students; future; Democratic Republic of Congo

Résumé - 'Je suis un intellectuel'. Guerre, jeunesse et éduccation supérieure à Goma (Est du Congo). Cet article ambitionne d'explorer, d'un point de vue empirique et dans une perspective processuelle, le lien entre éducation supérieure, guerre et aspirations des jeunes dans l'est du Congo. Les étudiants constituent un groupe social pertinent, ainsi qu'une focale ethnographique adéquate, pour décrire les moments et les processus d'autoreprésentation, de construction identitaire et de positionnement social. Ainsi, cet article analyse la manière dont les étudiants perçoivent les opportunités qui s'offrent à eux et comment, dans l'avenir, ils comptent accomplir leurs rêves les plus profonds. Mon argument est que l'université est un espace contesté qui reflète la société. Ainsi, les expériences et pratiques sociales des étudiants en rapport avec le milieu éducatif offrent une meilleure compréhension de la nature complexe des politiques patrimoniales, des équilibres de pouvoir en transformation, de l'appartenance sociale et de l'intimité qui sont au cœur de l'imagination d'un avenir meilleur pour les jeunes.

Mots-clés - Éducation supérieure ; jeunesse ; étudiants ; avenir ; République Démocratique du Congo

Resumen - 'Soy un intelectual'. Guerra, juventud y educación superior en Goma (Este de Congo). Este artículo pretende explorar, desde un punto de vista empírico y en una perspectiva procesual, el vínculo entre educación superior, guerra y aspiraciones de los jóvenes en el Este del Congo. Los estudiantes conforman un grupo social pertinente, así como un punto focal etnográfico adecuado para describir los momentos y los procesos de auto-representación, de construcción identitaria y de posicionamiento social. De manera que este artículo analiza la forma por la cual los estudiantes perciben las oportunidades que se les ofrecen y cómo, en el futuro, pretenden cumplir sus sueños los más profundos. Mi argumento es que la universidad es un espacio contestado que refleja la sociedad. De manera que las experiencias

\footnotetext{
* Silke Oldenburg, Senior Lecturer and Post-Doctoral Researcher, Chair of Social Anthropology, University of Basel, Switzerland, silke.oldenburg@unibas.ch
} 
y las prácticas de los estudiantes, en relación con el medio educativo, ofrecen una mejor comprensión de la compleja naturaleza de las políticas patrimoniales, de los equilibrios del poder en transformación, de la pertenencia social y de la intimidad que están en el corazón de la imaginación de un futuro mejor para los jóvenes.

Palabras claves - Educación superior; juventud; estudiantes; futuro; República Democrática del Congo

\section{INTRODUCTION}

THE PURPOSE OF THIS PAPER is to explore, at an empirical level and with a processual view, the relationship between education, war, and youths' aspirations in Eastern Congo. Higher education in Eastern Congo's setting of protracted violent conflict has achieved little scholarly attention so far: thus, this article tries to bridge this gap by asking how students imagine and navigate the different opportunity structures generated by the context of war and uncertainty. The objective is to present students - although privileged to a certain degree - as "ordinary" youths who most likely differ from the prominent image of marginalized youths on the continent. Specifically, this contribution focuses on Goma's university milieu. Building on ethnographic fieldwork with youths in Goma since 2008, this article addresses the experiences and goals of university students in a context of protracted violent conflict and humanitarian intervention.

Students are a relevant social group and an adequate ethnographic lens to describe moments and processes of self-staging, identity formation and social positionality. Therefore, this article explores how students imagine their life chances and how they aspire to accomplish their goals in the future. I argue that university is a contested space that mirrors society. Thus, students' experiences and social practices in relation to the educational realm offer important insights into the complex nature of patrimonial politics, shifting power balances, social belonging and intimacy, which are, as I argue, at the heart of the youthful imagination of a better future.

I refer to university as a particular milieu where different social storylines are discussed as "tribalism", "corruption", "sex" or "modernity". Here, education embraces a multitude of perspectives and mirrors the regional conflict dynamics, offers knowledge and networks, is a space of freedom, articulation and experimentation, a platform of pleasure with peers, of solidarity and love and it contains the potential for political activism. As Goma's education sector is equally shaped by the region's violent conflict scenario and its manifold consequences, shifting opportunity structures arise. Framing the concept of youth emically as a social practice of "searching, struggling and stumbling" (Oldenburg 2016) the opportunity structures will be discussed according to these different storylines.

The emic perception sheds light on how youth is imagined and referred to in local discourses. The big challenge for any ethnographic study on youth is its "fuzziness" (Van Dijk et al. 2011: 5), Youth is always entangled in global discourses and local power arrangements so it seems more relevant to ask who adopts the label of youth, 
why, in which situation, instead of reconfiguring contemporary notions of youth as a "phenomenon" or oversized analytical "concept" (Van Dijk et al. 2011). The question of whether one can speak of youth as a distinct social category at all becomes particularly evident in regard to students who might appear as very "ordinary" in a conflict zone as they are not the typical icons of young men and women with Kalashnikov rifles in hand (Oldenburg 2016). At first sight they could not be more different to street youths in other contexts of violent conflict as for example Vigh or Utas have shown (Vigh 2006; Utas 2005). However, the students' own usage of the "youth-label" and their interpretation of the situation shows how they assign meaning to their surroundings. This ability contradicts an often external, adult portrait of youth in contexts of armed conflict as a "lost generation" while it indicates their strategic use of the very same label, "navigating" socially created landscapes of being and becoming (Christiansen et al. 2006).

Goma is a promising setting to concentrate on education. Generally, there have been profound changes affecting university students in the Democratic Republic of Congo. As in other African contexts, the first generation of students following independence belonged to the most privileged group while successive generations have been faced with deteriorating living conditions and bleak prospects after graduation (Konings 2005: 161). In Eastern Congo, Goma has been shaped by social velocity and profound demographical transformations since the end of the 1980s. It is in the centre of violent conflict, humanitarian crisis, and ecological threats from the active volcano Nyiragongo, and attracts many social actors for business, politics, refuge and education. That means, Goma as a conflict zone is both a setting of insecurity and opportunity alike (Büscher \& Vlassenroot 2010). Furthermore, according to MacGaffey, "revolutionary changes in education will take place if one mode of production gives way to another" (1982: 239). Eastern Congo's economy has been diversified by the presence of international peacekeeping forces, humanitarian agencies, multinational trading companies and military commanders, which all mark the city visibly by investment in infrastructure and services while also having an impact on youths' perceptions of life chances (Jennings 2014; Oldenburg 2015).

Thus, this article presents some insights into how Goma's students reflect on their possibilities to engage and benefit from these opportunities. In this sense, "being an intellectual", a comment made by a 19-year old male university student, is connected to the many ways Goma's political economy shapes students' choices about political endeavours, social identities, intergenerational positions and subjectivity. Therefore, "I am an intellectual", epitomises simultaneously many things at once. It demonstrates first the agency of youths to position and label themselves strategically in a way that might help them to approach the powerful and the rich in order to enter beneficial networks with local Big Men or international organisations. Second, it brings on an elitist rhetoric which constructs a sharp division between the self and the other, a "civilized urban" and a "traditional rural" identity. Third, it carries on 
the one hand the nostalgic glimpse of past privileges and powers while on the other hand it alludes to generational tensions, demonstrating the students' claim to become part of the national elite and replace the old one. Fourth, it embraces an often neglected, yet very important issue, namely the belief in one's own mental capacities, therewith providing self-worth and preserving social value in times when nothing seems to be certain.

By demonstrating their sophistication, eloquence and imagined superiority, students refer to interpretative schemes through which they depict and analyse possible futures. Often, education is referred to as major step in a trajectory towards promising life chances. As (higher) education is a scarce resource, the university is one particular institution that embodies hope and prospects, and young people struggle to engage with these formal institutions in Goma as elsewhere (Cole \& Durham 2008: 16). As Cati Coe pointed out "schools are one of the most sustained zones of contact most people have with the state" (Coe 2005: 4). This reproduces ambivalent scenarios of power and inequality as Pierre Bourdieu has famously pointed out or Paul Willis and Antony Simpson have shown in their seminal ethnographies on working class youths in the UK or a boarding school in Zambia (Bourdieu \& Passeron 1977; Willis 1977; Simpson 2003).

Settings of war and protracted violent conflict, like North Kivu's provincial capital Goma, often produce generic labels as the famous notion of youth as a "lost generation" (O'Brien 1996) or more recently being "stuck" (Sommers 2012), in "waithood" (Honwana 2012), or threatened by "social death" (Vigh 2006). These settings evoke iconic images of youth as either Kalashnikov-carrying perpetrators or big-eyed victims of violence. Particularly in situations of social turmoil, their ambivalent potential is prominently related to the oxymoron of being either "makers and breakers" or "vanguard or vandals" of society (De Boeck \& Honwana 2005; Abbink \& Van Kessel 2005). This confirms Deborah Durham's statement that "youth are at the heart of the social imaginary" (Durham 2000; 2004: 601). However, obviously, these dichotomist perspectives do not adequately reflect the youths' selfidentification and tend to reproduce stereotypes rather than to depict the diversity of juvenile identities in conflict settings.

The article starts by illustrating Congo's education sector, tracing back the nostalgic search for an elitist equivalent amongst today's students in Goma's educational space. Structural components as persistent patronage networks and new pillars generated by the conflict setting will be analysed here. This is followed by students' perceptions of the educational realm as well as its assigned perils and promises. Here, I highlight the emic perception of education as a direct link to future employment, its relation to corruption, conflict and hopelessness, but also peace and "modernity", and finally as a particular form of "becoming a somebody" (Langevang 2008). Ethnographically, I concentrate on several gender-specific practices which demonstrate how students imagine their future and how they try to make it happen. Staging oneself as intellectual, analysing various opportunities and behaving flexibly 
and persistently seem to be locally perceived as successful attitudes to attain social status while failure is connected to idleness and stupid reasoning. For students particularly, this failure might become a trap in itself, which I frame as dramaturgic drop height in this article, exploring the rift between the expected and the possible (Vigh 2006: 41).

\section{SOCIAL HISTORY OF EDUCATION IN DR CONGO}

Reminiscences of a seemingly glorious past of university graduates as the respected elite, are foreign to today's youth. Higher education has declined rapidly since the 1980s because of the retreat of the Congolese state from public financing due to structural adjustment programs implemented by the World Bank and IMF and Mobutu's infamous reign of "kleptocracy" that led to an overall administrative breakdown and economic scarcity (Schatzberg 1982).

Aspirations of belonging to a desired elite status prevail in the minds of the students, with hopes that their hard work, their networks and strategies will enable them to climb up the social ladder. However, this also represents a crucial indicator of generational tensions in DRC which are often articulated in the famous metaphor of "the old dinosaurs" who hinder youths from moving up the social ladder. Jan Vansina (1980) calls this the "lineage ideology". Hereby, he refers to the gerontocratic order which suggests that youths will one day take up the social position of their elders. Yet, a seemingly "natural" generational change does not happen. Instead it is replaced by the locally framed idea of "elite recycling" ("recyclage des élites") which excludes the majority of the population from access to power and extends structural inequality.

With decolonization, educated Congolese took over their bosses' posts when these left when independence was achieved in 1960. Georges Nzongola-Ntalaja identifies a close relation between educational terms and social class division after independence. He states: "The popular label intellectual identified both the new national bourgeoisie of politicians, bureaucrats, entrepreneurs, and wealthy traders and also the second echelon of clerks, teachers, policemen, and soldiers. The nonintellectual lower classes were identified by occupation, from petty traders through urban and rural workers, peasants, and the unemployed." (Nzongola-Ntalaja 1970: 518)

Congo's first university was founded in 1954 in Kinshasa to "train an urban intellectual elite for the Belgian Congo" (Tsakala \& Bongo-Pasi: 2004: 83). It has been argued by many authors that the colonial trinity of state, companies and missions was solid. However, Patrick Boyle (1995) in his analysis of the so-called "school wars of the 1950s" has convincingly analysed the fragile relationship and the resulting power struggles between the colonial state and the church for control over the education sector. This struggle reflects the fear of colonial administrators that the university might develop into a "seed-bed of revolution and insurrection" (Boyle 
1995: 457) while having a preference for providing moral rather than academic instruction to the population (Young \& Turner 1985: 111). To counter youths' potentially violent behaviour, formal education was appreciated to keep them occupied and busy (Burgess 2005). ${ }^{1}$

These "school wars" had a huge emancipative effect on the Congolese as they manipulated and used these internal frictions between colonial administration and the church to their own benefit (Boyle 1995: 463). As a consequence, schooling expanded quickly as a key to social advancement and it created and established the intellectual figure of the évolué, the literate Congolese man who usually worked in white-collar jobs as for example Lumumba in the colonial post office (Mianda 2002; Monaville 2013). This colonial terminology is closely linked to the symbolic dimensions of education, namely progress and modernity, which the évolués (lit. "those who have emerged") claimed in order to differentiate themselves from the masses (Willame 1972: 24; Young \& Turner 1985: 113).

After Congo's independence, the educational realm flourished and while many elements of the colonial infrastructure went into decay, education thrived until the early 1970s. Yet, Mobutu's infamous reign led to an implosion of the education budget as economic scarcity, administrative break-down and structural adjustment programs in the 1980s signified a crucial step in the withdrawal of the Congolese state from the public realm. Actually, among African countries, Mobutu's government was spending the smallest amount of its national budget on education (Boyle 1995: 467) which explains the reliance upon patronage networks that remained a rather constant factor over time.

Kristof Titeca and Tom de Herdt have analysed the paradox of a nearly nonexistent state administration while public services continue to be organized and provided by non-state actors such as the church (Titeca \& De Herdt 2011: 214). Titeca and De Herdt have demonstrated the significance of the state image which remains rather uncontested even when alternative actors take over the provision of public infrastructure and services. ${ }^{2}$ Remarkably, even if DRC has a bad reputation for its economic performance, it performs better than average in regard to education as the state budget is replaced by higher contributions paid by parents (Titeca \& De Herdt 2011: 222f.).

This is also comparable to today's setting. Even if the state is weak and contested, it nevertheless remains a point of reference for manifold actors. In this sense, the protracted violent conflict influences new opportunity structures in the educational

\footnotetext{
${ }^{1}$ This is still a frequent comment on school drop outs suggesting that every young person without occupation is prone to negative behaviour. This perception is shared by many (inter)national development organizations and in this frame youth can be framed as "ideology" (Van Dijk et al. 2011). 2 There is a huge field of discussions debating the state of the state in the Congo. While the provision of public goods seems to be utopian, the state as a point of reference remains crucial. Remarkably this is true even in the context of violent conflict where violent actors don't aim at destroying the state but try to integrate into its formal rank system (Vlassenroot \& Raeymaekers 2009).
} 
realm as well. As the figure of the évolué lost momentum, other forms and figures of accumulation have come up (Banégas \& Warnier 2001: 6). As colonialism introduced new pathways to social mobility, war and humanitarian intervention since the 1990s offered new kinds of opportunities for education and employment. In former times, being a state functionary meant having a guaranteed salary and prestige. Today, new elites have replaced or coexist with former ones (Büscher \& Vlassenroot 2010). This is particularly true for Eastern DRC's context of social velocity. Armed actors, wealthy traders or humanitarian staff all provide different services, with their own agendas replacing the state without destroying its "image". Due to war and humanitarian crisis, the focus on Goma's educational landscape has increased and flourished slowly but steadily with the foundation of its first university in 1989.

\section{GOMA AS A CENTRE OF EDUCATION AND WAR DYNAMICS}

Goma hosts two universities and several higher education institutions. Getting into university is first and foremost an issue of money. As long as you pay, you will most likely enter the lecture room. The fees are between 150 Dollars for public Unigom and 250 Dollars for private ULPGL per academic year (status 2009). Most students need to have a variety of jobs to earn this money. Even the ones who manage to overcome all the monetary obstacles are often plagued by the fact that their living conditions are not favourable for their studies. Many students lament that they cannot concentrate with an empty stomach or that there is no room at home to study.

Universities as spaces mirror socio-political developments. Political frustration is high in Goma's universities where complaints about corruption, bad governance and moral decay are omnipresent. On the other hand, students are perceived as a potential threat to the social order as they are known for their political activism and a basis for mobilisation. Frequently, they demonstrate against the augmentation of study fees, the shortfall of classes due to lack of salary for the lecturers and against the political situation in general.

The student associations at Goma's universities emulate socially existing patterns of organisation. Ethnic university politics are on the daily agenda and student organisations try to exert political influence. They conjure ethnic self-conception and solidarity; serve as a dating platform, as a convivial space of encounter for newcomers, as a pillar of solidarity in case of illness and as a sign of stability in times of uncertainty. Officially, ethnic based student associations are prohibited, yet they exist nevertheless and are organised hierarchically reflecting Kivu's demographics. This means that in Goma, dynamics of violent conflict shape urban life and university equally: There exists a strong rivalry between the biggest ethnic population groups - the autochthonous trading elite of the Nande, the so-called Rwandophones (Hutu and Tutsi) as well as the Bashi from South Kivu. The student body mimics the regional power constellations (e.g. the ethnic group of the Nande would not form a coalition with the Banyarwanda students and vice versa). 
Furthermore, the ethnic identity of the director of Unigom (Hutu) and ULPGL (Nande) is a frequent topic of discussion when students feel treated in an unfair way or sense a scandal.

The student council reflects the national parliament: There are ministries whose posts are fiercely contested and negotiated as they imply contacts and money and establish an inner hierarchy at the university. ${ }^{3}$ With a post as minister, one is assigned two guards from the "university brigade" whose task is to protect the respective minister from troublemakers. This means that the university is organised as a state in the state. The university brigade is coordinated by the student minister of defence and plays a major role during the Bleusaille (test of courage) or the defence of theses. Its historical legacy can be traced back to the student uprisings against Mobutu in Lubumbashi in 1988 which were violently quashed. Still today, students will refer to Lubumbashi (and even Soweto, South Africa) to interpret their right to self-defence.

The socio-political context and its historical roots shape students' perception of their societal position as well as their tactics to succeed in achieving their goals. Conceiving oneself as "being intellectual" therefore has various meanings which will be explored in relation to different social practices.

\section{URbaN YOUTH AS "INTEllectuals": PERSPECTIVES, PERILS, POTENTIALITIES OF EDUCATION IN GOMA}

Most of the existing literature on higher education in times of persistent war concentrates on university students' role in political struggles where they are pictured as "rebels and heroes" or as moderate citizens well adapted to precarious conditions surrounding them (Konings 2005: 163). The following section provides a brief overview of different topics that were frequently raised by the students in regard to education during my fieldwork.

"Talking about the quality of education: there is none: The buildings, the material, the manuals, the programme, nothing. Today, even the university is no longer as it was before. There used to exist only few higher education institutes and universities, but these were quality. Today, a student rests at home without studying and gets a diploma at the end of the academic year. Guess why. As teachers are no longer paid adequately by the state, they take whatever they get offered. And you know: This one succeeded because he offered something to the teacher and that one failed because he did not offer anything. Honestly, in Congo the educational system is down." (Martial, 28 years, international relations, 24/11/2008)

In a context where all influential social positions - civil service, trade and commerce, army and last but not least the international humanitarian sector - require

\footnotetext{
${ }^{3}$ This is comparable to the emergence of the "évolués clubs" in various Congolese cities during the preindependence period, where "victory in a presidential campaign within a club could open the door to a similar post on the outside" (Willame 1972: 26f).
} 
diplomas, higher education is a topic that arises and is shrouded in myth in many conversations with youths in Goma:

"When I sat with three members of the student body in a local bar, a soldier approached us to invite us to the table of his superior. The students started discussing in muffled voice the ambivalence of this offer which could possibly open up new avenues towards a career in the army or alternatively put us in danger. One student drew a direct link between being a student now and becoming a general in future." (Fieldnotes, Soleil Palace, 08/07/2009)

During my fieldwork, I asked several youths about their opinion of obligatory military service. Particularly male students were in favour of it, imagining the advantage they would have to climb up the career ladder easily, reflecting on the low level of education of the majority of military staff. In Goma, education is strongly attached to political dimensions of violent conflict. Politics of inclusion and exclusion to the field of education are on the one hand channelled through an unequal access to institutions. This is more or less the norm for students in many educational systems. In Eastern Congo, on the other hand, mechanisms of exclusion might result in a rather direct inclusion into power constellations and patronage networks shaped by more than 20 years of violent conflict. Wazir, a student of International Relations opines: "An obligatory military service would be good because the whole population would be engaged. Yet, on the other hand all the marginal mentalities would be included as well, the mentalities of those who engage in banditisme, rebellions and so on. Nevertheless, I think this is a good idea." (Wazir, 32, international relations, 13/08/2009)

Students' ambitions to align themselves with politicians or high-ranking military personnel and envisioning these careers as highly desirable is one hint that war has become but one domain of everyday life (Richards 2005). The social capital these students intend to acquire is based on their social position and their self-perception as smart and inventive, capacities they tend to see as useful to develop military tactics and strategies. Wazir continues: “... What would be good is that it would not only be the Bashenzi (the dumb ones) but as well intellectuals, those who have been to school, those who can analyse. Most of Congolese soldiers have never seen a school from within." (Wazir, 32, international relations, 13/08/2009)

As the majority of Congolese soldiers is uneducated, students imagine a higher probability of entering the military rank system on graduation even if education per se does not matter as much as systems of patronage.

Another way students make use of the underlying conflict dynamics is by referring to discourses of "non-violence", a trope brought forward by omnipresent humanitarian agencies. A 25-year old student from public Unigom claims ambitiously: "I as an academic will bring my country forward to the place it deserves." (Fortinet, 25, rural development, 28/07/2008) 
This highly personalized narrative refers to an imagined agency of students in general. Many students seem to be generally confident about their future contributions to a peaceful society and position themselves in the framework of humanitarian workshops often as decision makers and future leaders. Student representatives such as Fortinet are often invited to talk at public events or on the radio as a crucial element of civil society. Their arguments are equally perceived as a threat of instability or as proof of intelligence. Goma's students consider themselves as privileged and aspire to social responsibility. Often, this idea of social responsibility is linked to the students' imagination of a peaceful society without corruption and tribalism and with strong socio-economic advancement. Being invited to talk on the radio or intervene in workshops, makes them present themselves as intellectuals, as elite and role models, connecting themselves to the historical figure of the évolué as will be explored in the next section.

Another recurring ambivalent motif is the social imagination of youths as potential rioters, challenging government politics and students' own perception of themselves as a "political force" ("Nous les scientifiques on est une force politique"). The nexus of education and violence here is remarkable. Education is normally ascribed with peace(fullness) while the illiterate ones are the ones in the wilderness. Here, imagination is twofold: It may be seen as a first step in a trajectory towards promising opportunities which may but do not have to entail political participation and violence. Most often, political frustration arises in regard to employment perspectives which are often linked to regional or ethnic identities. Thus, a frequent complaint relates to issues of clientelism or favouritism, as Guillaume explains:

\footnotetext{
"There is something that we, the scientists call 'complex mentality'. This happens everywhere. That's why I tell you, when I graduate, I will be influenced by the job offers of NGOs. But you know...If I am the boss, I will be always influenced to take in "my people". This is really an African thing. I condemn this, this is a problem. Even in the university. If you are from the same tribe as the professor, this will help." (Guillaume, 29, Law, 25/08/2009)
}

Another student adds: "If you don't have five years of experience, you need to be a friend, a brother or a cousin of the director." (Kara, 25, communication, 25/08/2009)

If the distribution of jobs is less organised by merit than by personal connections, these practices are locally called "tribalism" or nduguisme (from ndugu: brother). They are highly contested, particularly when there is no "brother" in an adequate position to help out. There exist many rumours that NGOs favour workers from a particular ethnic group and restrict the access to employment opportunities. This is true in many contexts but its effects in a volatile conflict setting might be different as resulting tensions might be manipulated in favour of one interest group or another.

Even if questions of inclusion and exclusion are common knowledge, Paul Richard's metaphor of education as a "passport to modernity" (1996: 138) is an important element for students' future hopes. The passport is about power and 
access to an imagined normative "good future". The majority of students I spoke with defined this trope (kutafuta maisha nzuri ya kesho) as a socially acknowledged position with sufficient material resources to make a living. As universities are mostly situated in urban settings, Richard's notion of the "passport" has a specific spatial component. This becomes evident in the following remark in relation to urbanity:

"Life in the city has many advantages. In the village possibilities are restricted. If you are born in the city, most of the youths are directly intellectual. There are schools, universities, but in the village there might be only one primary school which might be closed because of the wars. A young person in a village wakes up in the morning and goes to the field. That is the only concern. But in the city, a person has to contemplate how to pursue one's projects and how to go ahead. Therefore, one is civilized in the city." (Moise, 24, economics, 24/11/2008)

This quote points to different dimensions of education and urban identity: the outspoken reference to a civilization discourse points to a constructed social division between "the rural" as supposedly backward and "the urban" as progressive. The assumed civilized life of an urbanite is brought together with a strong desire for progress and the wish to take part in urban consumption practices, leaving work in the fields behind or escaping the disputed conflict spaces of Kivu's hinterland. Manifold opportunities seem to be visible in the city which requires intellectual capacity as one needs to organise the more complex offer and struggle to make the possibilities work for oneself. Obviously, many students are not that successful, they stumble and fail. This is also observed by "street-corner" youth:

\begin{abstract}
“On a sunny day, two young petrol sellers next to Goma's public university observe the hustle and bustle around graduation day. Students in colourful academic gown, surrounded by friends and proud family members parade along. The petrol sellers observe them quietly when another friend of the group comes back from a little shop. He makes a disparaging gesture towards the graduates and says: 'Eh, ili ni augmentation du chômage' (loosely: 'unemployment rises')." (Fieldnotes 19/09/2008, Goma)
\end{abstract}

This bitter tone, followed by the laughter of his friends suggests a truism of higher education in Goma: Even with a diploma in hand, you might fall deep. This is what I conceive of in the dramaturgic notion of "drop height", illustrating the discrepancy between high expectations and disappointed dreams which will be taken up later on.

\title{
BEING AN INTELLECTUAL: NOSTALGIA FOR AN ELITE PAST AND OPPORTUNITIES TO BUILD THE FUTURE
}

As imagination is a social practice, let's take a look at different gender-specific ways of relating to education's perils and potentialities and shedding light on what "being an intellectual" means for students' everyday lives, their aspirations for the future and educational itineraries today. 
My first example is from the former $\mathrm{CNDP}^{4}$ fiefdom of Kitchanga in Masisi where I met two female students from Goma. They were studying Law at the private university ULPGL and told me that they regularly came to Kitchanga with their peers during the summer. "Only here we succeed to breath freely", 23-year old Mapendo explained forthrightly. Both students had undergone "ideological training" and were engaged to CNDP commanders. Another time when I met Mapendo back in Goma, she told me about how she fell in love with "her" CNDP commander which was in the framework of their student association in Bukavu. Mapendo is the eldest girl from a relatively well-off trading family. To the extent that political frustration and precarious conditions arise, not only male but also female students develop tactics to get along. This not only has implications on the participation in politics, yet opens up new marriage schemes as well.

While some students try to align themselves with politicians, others seek their way to upward mobility in the ranks of the different existing militias. For example, Fiston, another law student from ULPGL prided himself on his possession of phone numbers of various important CNDP members which he showed to me with a feeling of importance. He was seemingly eager to demonstrate his own connectedness to influential people.

Being connected is a very important and time-consuming practice for students. Students feel enormous pressure to perform for their own but also their families' sake. Even when they work hard and get close, the likelihood of failure remains. Nadine, a student of Languages was fantasizing about marrying a Muzungu, a white husband. She and her student friends were deeply involved in practices popularly called Chik, Chok, Chek.

The phenomenon of Chik, Chok, Chek ${ }^{5}$ describes the tactical juggling by young women of different boyfriends at the same time at Goma's universities. The Chik is the handsome and elegant one, the one with whom the girls like to go out and want to be seen with. The Chok is smart and hard-working and supports her in her studies while she is dating the Chek, often a better-off, older man who can afford to support a lover next to his family life. ${ }^{6}$

\footnotetext{
${ }^{4}$ During my field stays in 2008 and 2009, the CNDP (Congrès National de la Défense du Peuple) under Laurent Nkunda was the most visible armed fraction in North Kivu and happened to siege Goma in October 2008.

${ }^{5}$ I stick to the spelling of Chik-chok-chek which a female student once jotted down for me. French expressions are often expressed with $\mathrm{k}$ instead of $\mathrm{q}$. Phenomena of transactional sex, or sex-formoney-exchange (Cole 2004), are labelled with different codes which change frequently as for example the term "Conte40", borrowed from accountancy. Cole describes similar processes in Tamatave, Madagascar, where French colonization brought new kinds of marriage patterns which opened up ways for women to gain a higher status (Cole 2010: 33ff.).

${ }^{6}$ This man is colloquially called the Kisacochi which is equivalent to the well-known "sugar daddy". Sacochi means bag in Swahili while $k i$ is a prefix for people. The sugar daddy might take care of tuition fees, beauty products or transport, etc.
} 
By longing for education, the university becomes a social arena where style is tested, self-staging is popular and marriages are negotiated. It is a space where young women acquire new knowledge and escape their well-behaved life in the family for a time (Adams 2009). While I got to know Nadine as a "connected girl" (fille branchée), one who is interested in fashion and flirting, Nadine's father was looking forward to her graduation day. He was engaged in Goma's civil society and quite aware of gender-mainstreaming programs within international NGOs. He expected Nadine to enter the humanitarian job market as either a secretary or translator. Nadine was also confident about this opportunity through education even when she preferred to imagine a better life by meeting "the perfect husband" in a NGO. In this example, the prospects for employment and raising one's status by smart marriages are intermingled. Particularly for women, marriage is still a determinant of well-being as it goes along with social security and upward mobility strategies. Education is here an important step to open up the opportunity to come into contact with promising contacts and expresses the idea of what constitutes a "good future".

As introduced in the beginning, Goma is a context with manifold actors and different economies. Not only the international organisations and militias but also local politicians and traders are attractive to establish networks with. Thierry, for example, was 31 when we met at a fair. He was studying International Relations and had been interested in politics from an early age. As a member of the Conseil de la Jeunesse (Youth Council) at the provincial level, he represented his ethnic community in university politics as a spokesperson. In this function, he quickly came into contact with important local Big Men, ${ }^{7}$ and he was taken on by one well-known patron who paid for his studies, brought him into his network, and supplied him with contacts. The patron was a big name in business in Eastern Congo under Mobutu and is now an influential politician. By funding Thierry, he hoped to gain influence on the student body, thereby using informal networks for his political ambitions. Thierry acted as an errand boy for him, and partly as a chauffeur. He was also able to conduct some business so that he could put aside some money and get a car. Furthermore, in his position with the Conseil de la Jeunesse he had a travel budget and as long as he did not use those funds and used his patron's networks to travel, he could put aside a large sum each half year. As a social actor, Thierry was well aware of how he ought to behave towards whom and how to plan strategically. He was able to judge which contact in which situation would be most beneficial and how to approach someone in order to form an alliance. Due to Thierry's success, the generational hierarchy in his family has been reversed, and he referred to himself

\footnotetext{
${ }^{7}$ Big Men politics are a vast field in DRC as prominent big men can be political, military or sociopolitical. In the literature, big men are often associated with Congo's war economy in which big men manipulate local actors and networks for their benefits. Important to note is that these social actors operate establishing alternative power structures to the state without being necessarily at its margins (De Koning 2012; Vlassenroot \& Perrot 2012).
} 
proudly as the grand of his family. His parents lived in South Kivu, but he acted autonomously and has helped two younger siblings to attend school. This example demonstrates the extent to which Thierry increased his social capital by smart investment strategies into social networks.

Today, the range of possibilities for patronage has been significantly differentiated by war and humanitarian organizations and has opened up new business relations. Thierry and his patron demonstrate the complexity of patron-client relationships. Although Thierry was dependent on his patron, his patron also benefitted from Thierry's influence on his peers. In the kin context, Thierry has reversed intergenerational relations, whereby he, instead of his father, was able to provide for his younger siblings, and furthermore, was able to invest his earnings in various sectors to diversify and enhance his chances of success. However, his success made Thierry cautious at the same time as he anticipated social and material envy everywhere and he often told me how to move in order not to expose himself too much to "bandits" as he would call them.

The diversification and straddling of milieus and opportunities is common for youths in general, but probably, it is most common in the university milieu. The above-mentioned tuition fees are not affordable for everybody every term. So students need to be pragmatic and diversify their efforts. Many students I met were aware of opportunities and tried to spread their chances through different milieus as much as possible. A good example is 22-year old Bahati who studied Rural Development. He was preaching in the mosque, providing animation at parties, was active as a secretary in his student association and helping out with a copy service in the neighbourhood. His weeks were filled with events and activities that could open up routes to different careers, however small the chance of success. When I asked him about his hectic life, he laughed and said: "il faut faire gauche droite dans la vie." This can be interpreted as looking for avenues left and right of the straight way to success. Yet, eventually all ways will end somewhere. He was proud of his managerial capacities. When the exams were approaching, he organised a little room for his friends and himself to study as in their tiny homes there was neither space nor calm to concentrate. As a very eloquent and smart student, he succeeded in having a grande distinction and earned a scholarship to study at the prestigious École Nationale $d^{\prime}$ Administration (ENA) in Kinshasa. His hard work and agility paid off.

The importance of education is not exclusively based on the belief of diplomas as a stable source of income. Rather, youths perceive the manifold opportunities offered through the education realm which might be of political but also of intimate character. Their efforts to diversify knowledge and broaden their networks is perceived as an important first step to secure a good future according to their own imagination. However, this is not necessarily crowned by success: Many students stumble, and unemployment is a broadly spread phenomenon among Goma's university graduates. Nevertheless, the way students use education as an institution and as an infrastructure shows their potential to act pragmatically. 
The students presented in this section straddle between different opportunities as much as possible. In a highly volatile context where conditions may change overnight, identifying and grabbing an opportunity when it comes up, is the most important ability. On a generational level, students complain frequently about the obstacles in their way or are attacked because of their supposed idleness and irresponsibility. However, nearly every student I met believed in his or her social mobility. Besides demonstrating political frustration through activism, manifestations and strikes, these practices are primarily related to youths' own performance reflecting a moral interpretation of social reality. Remarkably, they tended to focus more on personal attitudes than on structural positions in society.

\section{CONCLUSION: HIGHER EDUCATION. TRYING HARD, FALLING DEEP?}

By focussing on their own individual capacities, their eloquence and imagined superiority, students lift up their self-image rhetorically. However, higher education raises expectations that will most likely not be fulfilled. This is what I frame as dramaturgic drop height, or in a more drastic way: the higher they reach, the deeper they fall.

There seems to exist an African predicament of youth. In the literature one finds catchy variations of more or less afro-pessimistic visions of youth confronting their "social death" as youths can't follow the socially accepted way into adulthood (Vigh 2006). They are "stuck" as Sommers (2012) shows for Rwanda or as Honwana (2012) has put it famously, find themselves in a stage of "waithood". However, the narratives presented have shown that they remain largely personalized. The imagined agency of youth is at odds with ideas about "waithood" or being "stuck", so that the question arises of why these notions appear to dominate the literature. Compared to the often marginalized young people of such studies, Goma's students as a particular group of youth seem to be too ordinary as they are not automatically connected to the long-lasting conflict context in the Kivus. However, I met many students that lived in similar conditions as described for other contexts of marginalization and insecurity. The particular opportunity structures generate imagination and students imagine opportunity structures at the same time so that the dominant tropes of youth are tropes of ideology (Van Dijk et al. 2011). Therefore, on the one hand, labelling is a means of social control to be exerted on youth, classifying them as a "lost generation", overly passive or idle. Remarkable here is that this classification always comes from an etic point of view - that means mostly from an adult perspective.

However, on the other hand, self-labelling as "being an intellectual" might refer to the social construction of an educated self. Many students in Goma I spoke to, try to realize their imagination to become a somebody in the future by being flexible and smart. Analogous to the emergence of the évolué, being socially recognized as an intellectual is closely tied to institutions of Western education. The access to knowledge, information and opportunities is accompanied by advice that flares up 
frequently and recommendations to work on oneself persistently: "You have to be dynamic", "you have to be on the move", "you have to be flexible" are all expressions to remind you which values may help you to make it in life. They reflect a capitalist ethos and mirror the students' imagination of future success. As has been shown, attributes like flexibility or perseverance are hard currency in a fast transforming context (Makhulu et al. 2010: 10). Therefore, practices like searching for opportunities and struggling to become a somebody are crucial to understand this complex setting and to be able to assign meaning to it. Studying the perspective of "ordinary youth" proves useful to demonstrate that not all young people in war-torn contexts perceive themselves as a "lost generation", "stuck" or close to "social death". By focusing mainly on seemingly "extraordinary" groups of youth, the focus on their supposed marginalization might hinder a more nuanced understanding of their actual life worlds.

"Being intellectual" is therefore a rhetoric of one's own performance and individual achievements rather than reflecting on the underlying structural conditions. Even if this holds true for many juvenile life worlds in Goma, for students, the drop height, the rift between high expectations and a potential deep fall is significant. In the popular local imagination for those who don't succeed in getting a job or entering promising networks, recognition is rare. Typical terms to denigrate the ones who stumble include yuma (idiot), mushenzi (villager) or nyama (meat). Even the choice of Swahili as a local language demonstrates their deportation to another social world.

My contribution shows how ideas about one's position in the world are intertwined with experiences of an overall context of crisis which shapes the youths' socio-political reflections and yearnings. I conclude by discussing the diverging effects of war on the meanings of youth and the importance of education.

In Goma, education is imagined as a meaningful basis to a civilized life and equally valued by children, youth and their families. Although many may be disillusioned by their everyday realities where ambitions remain unfulfilled, education as a collective imagination persists as a point of orientation - be it in a hopeful or a sobered way. Diplomas are regarded as a pathway to upward social mobility and to becoming a "modern" individual. For youths, they represent the first step to employment and thereby to a socially respected life. Besides the economic dimension of income, social and existential dimensions of achieving the ideal image of an adult, as social prestige and a meaningful identity, are important. However, in reality, the link between being educated and obtaining a job is far from self-evident, particularly in a highly volatile context where everything can change overnight. Nevertheless, besides an informal "school of hard knocks", the expectations and ambitions of many young people in Goma are still directed towards the formal education sector. The belief in making it one day seems to be surprisingly strong and youths remind themselves to be patient. For example, one of my interlocutors, a petrol seller, repeatedly took an exam for the Diplôme d'État for several years. He 
failed every time due to limited preparation, I suppose. However, the idea of obtaining the degree, and thereby opening up new avenues for life chances seemed to be very attractive to him.

The frequently heard allusions of "being an intellectual" finally demonstrate different tactics in regard to the daily challenges of students like the limited employment opportunities in Goma's formal sector. In times of political upheaval, social change and economic crisis, they try to find ways which promise a stable future. In a context marked by 20 years of armed conflicts, it is war itself that has become a trigger for social mobility as the dynamics of war with its shifting opportunity structures embrace all realms of Goma's society. As I argued, education and "being an intellectual" play a major role in young people's self-perception, connecting oneself to the influential ones, distancing oneself from "the uncivilized masses" and "old elites" towards becoming a respected person with social prestige and personal autonomy. Being an intellectual can thus be read in Bourdieu's sense as a symbolic mechanism of social distinction by education. To know that one belongs to the privileged few provides a basis for self-worth and pride but also implies power. Thus, education is still seen as a powerful tool for emancipation. Even if students are aware of failure, education remains a highly important aspect of youthful identity. Even if their "passport to modernity" might not guarantee them a better life, it bolsters their imagination of a better future and provides the belief that with a diploma in hand, opportunities to find work are better than without it.

\section{BIBLIOGRAPHY}

ADAMS M. 2009 «Playful Places, Serious Times: Young Women Migrants from a Peri-Urban Settlement, Zimbabwe », Journal of the Royal Anthropological Institute 15 : 797-814.

BANÉGAS R. \& WARNIER J.-P. 2001 « Nouvelles figures de la réussite et du pouvoir », Politique Africaine 82(2) : 5-23.

BOURDieU P. \& PASSERON J.-C. 1977 Reproduction in Education, Society and Culture. LondonThousand Oaks : Sage Publications.

BoYLE P.M. 1995 "School Wars. Church, State, and the Death of the Congo ", Journal of Modern African Studies 33(3) : 451-468.

BURGESS T. 2005 «Introduction to Youth and Citizenship in East Africa », Africa Today 51(3) : 7-24.

BuESCHER K. \& VlASSENROOT K. 2010 «Humanitarian Presence and Urban Development : New Opportunities and Contrasts in Goma, DRC », Disasters 34(2) : 256-273.

COE C. 2005 Dilemmas of Culture in African Schools. Youth, Nationalism, and the Transformation of Knowledge. Chicago-London: The University of Chicago Press.

COLE J. 2004 «Fresh Contact in Tamatave, Madagascar: Sex, Money, and Intergenerational Transformation » American Ethnologist 31(4) : 573-588.

COLE J. 2010 Sex and Salvation: Imagining the Future in Madagascar. Chicago: The University of Chicago Press.

Cole J. \& Durham D. 2008 «Introduction», in J. Cole \& D. Durham (eds.) Figuring the Future. Globalization and the Temporalities of Children and Youth (3-23). Santa Fe: School for Advanced Research Press. 
CRUISE O'BRIEn D.B. 1996 «A Lost Generation ? Youth, Identity and State Decay in West Africa », in R. Werbner \& T. Ranger (eds.) Postcolonial Identities in Africa (55-74). London : Zed Books

DE BOECK F. \& HONWANA A. 2005 «Introduction : Children and Youth in Africa. Agency, Identity \& Place", in A. Honwana \& F. de Boeck (eds.) Makers and Breakers. Children and Youth in Postcolonial Africa (1-18). Oxford : James Currey.

De Koning R. 2012 «Big Men Commanding Conflict Resources: The Democratic Republic of the Congo", in M. Utas (ed.) African Conflicts and Informal Power. Big Men and Networks (224-247). London : Zed Books.

DURHAM D. 2000 "Youth and the Social Imagination in Africa: Introduction to Parts 1 and 2 », Anthropological Quarterly 73(3) : 113-119.

DURHAM D. 2004 «Disappearing Youth. Youth as a Social Shifter in Botswana», American Ethnologist 31(4) : 589-605.

HANNERZ U. 1969 Soulside. Inquiries into Ghetto Culture and Community. New York- London: Columbia University Press.

HonwanA A. 2012 The Time of Youth: Work, Social Change, and Politics in Africa. Boulder, CO: Kumarian Press.

JenNingS K.M. 2014 «Service, Sex and Security : Gendered Peacekeeping Economies in Liberia and the Democratic Republic of the Congo », Security Dialogue 45(4) : 1-18.

KONINGS P. 2005 «Anglophone University Students and Anglophone Nationalist Struggles in Cameroon ", in J. Abbink \& I. van Kessel (eds.) Vanguard or Vandals. Youth, Politics, and Conflict in Africa (161-188). Leiden-Boston : Brill.

LANGeVAng T. 2008 «'We are Managing!' Uncertain Paths to Respectable Adulthoods in Accra, Ghana », Geoforum 39 : 2039-2047.

MACGAFFEY W. 1982 "Education, Religion, and Social Structure in Zaire», Anthropology \& Education Quarterly 13(3) : 238-250.

MAKHUlu A.-M., Buggenhagen B. \& JACKSON S. 2010 "Introduction », in A.-M. Makhulu, B. Buggenhagen \& S. Jackson (eds.) Hard Work, Hard Times. Global Volatility and African Subjectivities (1-27). Berkeley : University of California Press.

MAZRui A. 1978 Political Values and the Educated Class in Africa. Nigeria : Heinemann Educational Books.

MiANDA G. 2002 "Colonialism, Education, and Gender Relations in the Belgian Congo: The Évolué Case ", in J. Allman, S. Geiger \& N. Musisi (eds.) Women in African Colonial Histories (144163). Bloomington : Indiana University Press.

Monaville P. 2013 Decolonizing the University : Postal Politics, the Student Movement, and Global 1968 in the Congo, Unpublished PhD Thesis, University of Michigan.

NzONGOla-Ntalaja G. 1970 "The Bourgeoisie and Revolution in the Congo », The Journal of Modern African Studies 8(4) : 511-530.

OldenbuRG S. 2015 "The Politics of Love and Intimacy in Goma, Eastern DR Congo: Perspectives on the Market of Intervention as Contact Zone», Journal of Intervention and Statebuilding 9(3) : 316-333.

OldenbuRG S. 2016 A Goma On Sait Jamais. Jugend, Krieg und Alltag in Goma, DR Kongo. BerlinWien : Lit Verlag.

RICHARDS P. 1996 Fighting for the Rain Forest: War, Youth and Resources in Sierra Leone. Oxford: James Currey. 
RICHARDS P. 2005 «New War. An Ethnographic Approach», In P. Richards (ed.) No Peace, No War. An Anthropology of Contemporary Armed Conflicts (1-21). Oxford : James Currey.

SCHAtZBerg M.G. 1982 «'Le Mal Zaïrois' : Why Policy Fails in Zaïre », African Affairs 81 : 337-348.

SiMPSON A. 2003 Half-London in Zambia. Contested Identities in a Catholic Mission School. London: Edinburgh University Press.

SOMMERS M. 2012 Stuck: Rwandan Youth and the Struggle for Adulthood. Athens, GA : University of Georgia Press.

TitecA K. \& De HeRdT T. 2011 «Real Governance beyond the 'Failed State' : Negotiating Education in the Democratic Republic of the Congo », African Affairs 110(439) : 213-231.

TSAKALA T.M. \& BONGO-PASI M.W. 2004 « The Diploma Paradox: University of Kinshasa between Crisis and Salvation", in T. Trefon (ed.) Reinventing Order in the Congo. How People Respond to State Failure in Kinshasa (82-98). London-New York : Zed Books.

VAN DIJK R., De Bruijn M., CARDOSO C. \& BUtTER I. 2011 «Introduction : Ideologies of Youth », Africa Development 36(3-4) : 1-17.

VANSINA J. 1980 «Lignage, Idéologie et Histoire en Afrique Équatoriale », Enquêtes et Documents d'Histoire Africaine 4 : 133-155.

VERHAEGEN B. 1966 Rebellions au Congo. Tome 1. Bruxelles : CRISP.

VIGH H. 2006 «Social Death and Violent Life Chances », in C. Christiansen, M. Utas \& H. Vigh (eds.) Navigating Youth, Generating Adulthood. Social Becoming in an African Context (31-60). Uppsala : Nordiska Afrikainstitutet.

VlASSENROOT K. \& RAEYMAKERS T. 2009 «Kivu's Intractable Security Conundrum », African Affairs 108(432) : 475-484.

VlassenRoOT K. \& PERROT S. 2012 «Ugandan Military Entrepreneurialism on the Congo Border», in M. Utas (ed.) African Conflicts and Informal Power. Big Men and Networks (35-59). London : Zed Books.

Willame J.-C. 1972 Patrimonialism and Political Change in the Congo. Stanford : Stanford University Press.

WILLIS P. 1977 Learning to Labor. How Working Class Kids Get Working Class Jobs. New York: Columbia University Press.

YOUnG C. \& TURNER T. 1985 The Rise and Decline of the Zairian State. Madison : The University of Wisconsin Press. 